\title{
The efficacy of protein supplementation in overcoming urea toxicity in sheep
}

\author{
By E. PAYNE* AND L. LAWS \\ Animal Research Institute, Department of Primary Industries, \\ Yeerongpilly, Queensland 4105, Australia \\ (Received 23 December I974-Accepted I I fuly 1975)
}

\begin{abstract}
r. In the first experiment sheep taken from pasture were given a low-protein diet for 6 weeks in individual pens. Then, for I week, groups were given a supplement of lucerne chaff, safflower meal or lucerne chaff plus safflower meal. In the second experiment eighteen sheep maintained on lucerne chaff rather than pasture were then depleted of protein to a greater extent by feeding on a restricted low-protein diet. Six of the sheep received a supplement of molasses throughout the period of protein depletion while six of the sheep on the basal ration received a supplement of safflower meal after 6 weeks on the low-protein diet.

2. The urea tolerance of the sheep, as indicated by blood ammonia levels after oral dosing with aqueous solutions of urea, was determined after the period of supplementation. 'Arginine synthetase' activity (combined activities of argininosuccinate synthetase $(E C$ 6.3.4.5) and argininosuccinate lyase $(E C 4 \cdot 3.2 .1)$ ) was determined in liver samples obtained by biopsy at various intervals during the experiment.

3. Supplementation for $7 \mathrm{~d}$ with $73 \mathrm{~g}$ crude protein (nitrogen $\times 6.25$ )/d increased the tolerance to urea, as indicated by reduced blood $\mathrm{NH}_{3}$ levels, and also increased 'arginine synthetase' activity.

4. Giving supplements of molasses delayed the onset of urea toxicity but not the extent of toxicity.

5. It is suggested that short-term feeding of protein concentrates to sheep before giving urea supplements can increase their tolerance to urea.
\end{abstract}

In Queensland, undernourished ruminants, particularly cattle, are frequently given a supplement of urea. To restrict intake to safe levels it is given as a 'lick', in a compressed block with other nutrients, or as a solution with molasses, using drum rollers or floats in troughs. Even though molasses reduces the rumen ammonia level, thus increasing the tolerance to urea (Lewis, 1957), over-ingestion of these supplements, with resultant urea toxicity, does occur. This happens usually in the first few days after introduction of the supplement.

Previous reports from this laboratory (Payne \& Morris, I969; Morris \& Payne, I970) have suggested that at the time when ruminants given a low nitrogen intake are given supplements, they are most vulnerable to urea toxicity. The results of these studies indicate that with low protein intakes, the activity of enzymes of the urea cycle is reduced, and thus the capacity of the liver to detoxify $\mathrm{NH}_{3}$ is reduced.

Any process that could increase the concentration or activity of the enzymes responsible for the conversion of $\mathrm{NH}_{3}$ to urea would probably increase the tolerance of ruminants to urea. Accordingly it has been postulated that short-term feeding of protein supplements to ruminants on reduced protein intake should increase the activity of the rate-limiting enzyme and, therefore, the urea tolerance. The

* Present address: Ruakura Animal Research Station, Ministry of Agriculture and Fisheries, Hamilton, New Zealand. 
Table I. Dietary regimens for sheep during Expts I and 2

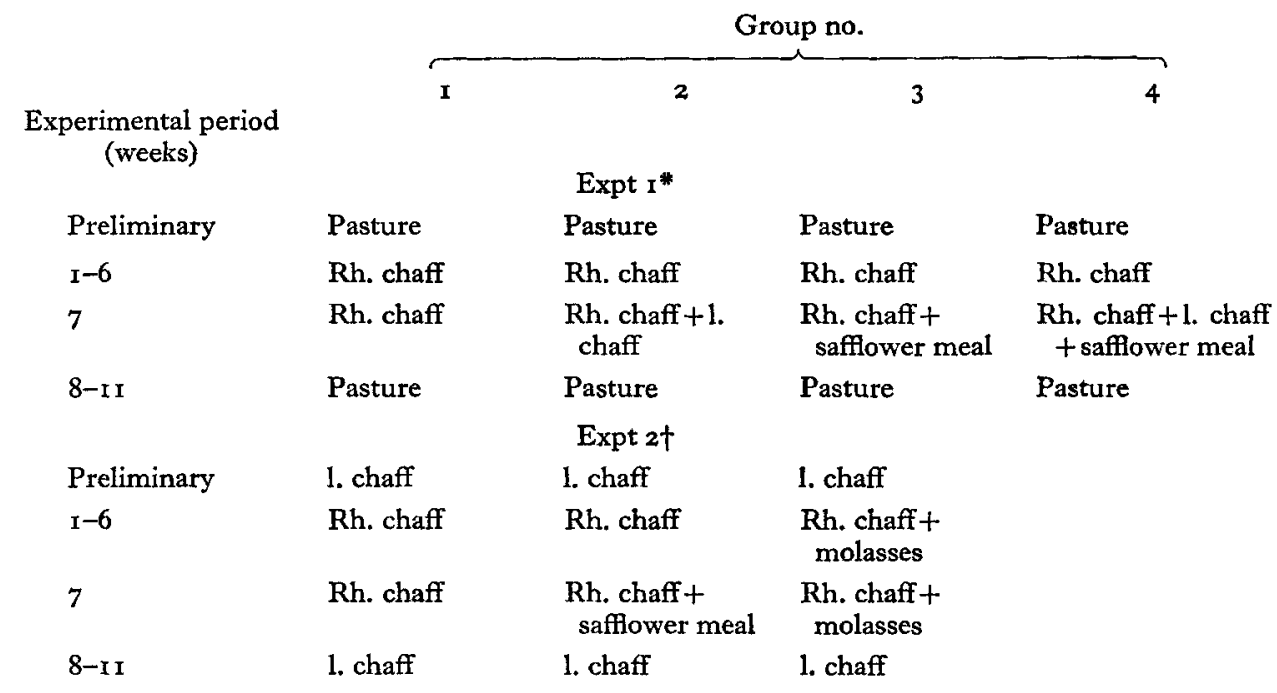

Rh. chaff, Rhodes-grass (Chloris gayana) chaff; 1 . chaff, lucerne (Medicago sativa) chaff.

* Each sheep received $500 \mathrm{~g} \mathrm{Rh}$. chaff/d. Supplemented sheep also received $500 \mathrm{~g} 1$. chaff/d or $170 \mathrm{~g}$ safflower meal/d.

+ Each sheep received $400 \mathrm{~g} \mathrm{Rh}$. chaff/d. Supplemented sheep also received $150 \mathrm{~g}$ molasses/d or I $70 \mathrm{~g}$ safflower meal/d. 1. chaff was fed ad lib.

rate-limiting step has long been acknowledged as the conversion of citrulline to arginine (Brown \& Cohen, r959; Schimke, 1962). Although 'arginine synthetase', the enzyme originally designated for this reaction, has since been found to represent two different enzymes, argininosuccinate synthetase $(E C$ 6.3.4.5) and argininosuccinate lyase $(E C 4 \cdot 3 \cdot 2.1)$, the measurement of the over-all reaction is still a measure of the rate-limiting step.

\section{EXPERIMENTAL}

\section{Animals and diets}

Expt I. Sixteen Border Leicester $\times$ Merino wether sheep with a mean live weight of $37 \mathrm{~kg}$ (range $34-44 \mathrm{~kg}$ ) were taken from pasture, divided into four groups of four animals by random stratification according to live weight, and housed in individual pens. The feeding schedules for the various groups of sheep are given in Table I. All sheep were given a basal diet of $500 \mathrm{~g}$ Rhodes-grass (Chloris gayana) chaff at 08.00 hours. During week 7 of the experiment, sheep in groups 2,3 and 4 received supplements mixed with their basal ration as indicated. Lucerne (Medicago sativa) chaff and safflower meal were given at the rate of 500 and $170 \mathrm{~g} / \mathrm{d}$ respectively.

Expt. 2. Eighteen Border Leicester $\times$ Merino sheep (fifteen ewes and three wethers) of mean live weight $32 \mathrm{~kg}$ (range $22-38 \mathrm{~kg}$ ) were removed from pasture and housed in individual pens. The feeding schedule was as given in Table r. After a 2-week preliminary period feeding on lucerne chaff $a d l i b$., the sheep were divided into three groups by random stratification according to live weight, each group containing one wether. Rhodes-grass chaff was given at the rate of $400 \mathrm{~g} / \mathrm{d}$. Sheep in group 3 were 
given a supplement of molasses at the rate of $150 \mathrm{~g} / \mathrm{d}$ together with the Rhodes-grass chaff. During week 7 sheep in group 2 received $170 \mathrm{~g}$ safflower meal/d.

\section{Diet analyses}

On an 'air-dry' basis the Rhodes-grass chaff, lucerne chaff and safflower meal contained $10.2,22.0$ and $65^{\circ} \circ \mathrm{g} \mathrm{N} / \mathrm{kg}$ respectively. Thus I $70 \mathrm{~g}$ safflower meal was isonitrogenous with $500 \mathrm{~g}$ lucerne chaff.

\section{Sampling and treatments}

In both experiments liver biopsy samples were collected at the beginning of the period on the low-protein diet and then at weeks 4,7 and II of the experimental period. Sampling intervals were chosen to indicate enzyme activity before underfeeding, during underfeeding, after supplementation and after recovery to normal food intakes. The sample taken during the period of underfeeding could not be taken immediately before supplementation as it was felt that liver biopsy only I week before a test for urea tolerance could confuse the results of this test. Sheep were not fed on the day the biopsy sample was taken until all handling, including testing for urea tolerance, was finished.

Liver samples were obtained by aspiration biopsy using the procedure described by Dick (1952) and the samples were frozen immediately in glass tubes in solid carbon dioxide.

\section{Urea tolerance test}

After the biopsy done at the end of the supplementation period (week 7 of the experimental period) all sheep were tested for their tolerance to urea by drenching with a toxic dose and monitoring the blood $\mathrm{NH}_{3}-\mathrm{N}$ levels for $2 \mathrm{~h}$. In Expt I the sheep received $0.4 \mathrm{~g}$ urea $/ \mathrm{kg}$ live weight and in Expt 2 the sheep received $0.45 \mathrm{~g}$ urea $/ \mathrm{kg}$ live weight because the sheep had been shorn recently. The blood samples $(2 \mathrm{ml})$ were injected immediately into $2 \mathrm{ml}$ ice-cold trichloroacetic acid solution $(200 \mathrm{~g} / \mathrm{l})$ and, after centrifugation at $0^{\circ}$, were analysed as soon as possible.

\section{Analytical methods}

Blood $\mathrm{NH}_{3}$ concentrations were determined by the method of Seligson \& Seligson (I95I) as described by Payne \& Morris (I969). 'Arginine synthetase' activity (combined activities of argininosuccinate synthetase and argininosuccinate lyase) was determined in undiluted liver homogenates prepared by quickly weighing the deepfrozen biopsy 'cores' and homogenizing with water ( $1: 19, w / v)$ using a PotterElvehjem-type homogenizer. After incubation using the method of Brown \& Cohen (I959) 'arginine synthetase' activity was determined by coupling the conversion of citrulline to arginine with hydrolysis of the arginine to urea by the addition of excess arginase $(E C 3 \cdot 5 \cdot 3 \cdot \mathrm{I})$. The urea was hydrolysed by excess urease $(E C 3 \cdot 5 \cdot \mathrm{I} \cdot 5)$ to $\mathrm{NH}_{3}$ which was then determined by the method for blood $\mathrm{NH}_{3}$ (Payne \& Morris, I969). One unit of activity was defined as $\mathrm{I} \mu \mathrm{mol} \mathrm{NH}$ formed/h at $38^{\circ}$.

DNA concentrations were determined by the method of Munro \& Fleck (1966) 

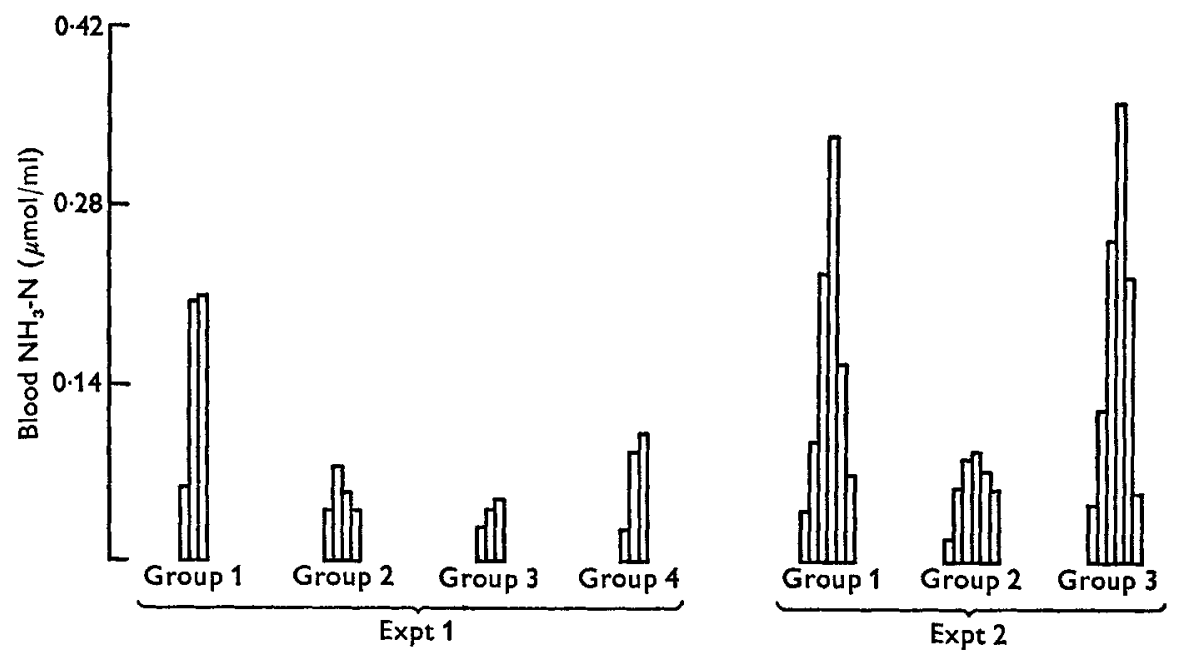

Fig. 1. Expts $I$ and 2. The individual values for the peak ammonia-nitrogen levels in groups of sheep after they had been drenched with toxic doses of urea at the end of the supplementation period (for details of the dietary regimens for the experimental period, see Table I). In the $7 \mathrm{~d}$ supplementation period the sheep received the following diets (g/d): Expt I: group I, 500 Rhodes-grass (Chloris gayana) chaff (basal); group 2, basal + 500 lucerne (Medicago sativa) chaff; group 3 , basal + I70 safflower meal; group 4 , basal +500 lucerne chaff +170 safflower meal. Expt 2: group I, 400 Rhodes-grass chaff (basal); group 2, basal + I 70 safflower meal; group 3 , basal +150 molasses.

using the modification of the diphenylamine method suggested by Giles \& Myers $(1965)$. Protein concentrations were determined on $I: 50(\mathrm{v} / \mathrm{v})$ dilutions of the liver homogenates by the method of Miller (I959).

The significance of the differences between the group means at the third sampling (after supplementation) was tested by analysis of variance using covariance adjustment for values at the second sampling.

\section{RESULTS}

\section{Expt I}

For each sheep the peak blood $\mathrm{NH}_{3}-\mathrm{N}$ levels obtained after drenching with urea are shown in Fig. I. Groups 2, 3 and 4 (supplemented for I week) had good tolerance towards the urea, and blood $\mathrm{NH}_{3}-\mathrm{N}$ levels did not increase to levels indicative of toxicity. In the control group (group $\mathrm{I}$ ), two of the three sheep had toxic levels of blood $\mathrm{NH}_{3}-\mathrm{N}$ which resulted in death, while the other sheep had no ill effects. The increased protein intake in group 4 , compared with groups 2 and 3 , appeared to result in a slight increase in blood $\mathrm{NH}_{3}-\mathrm{N}$ rather than a further decrease but due to the small numbers of animals, accentuated by some deaths during biopsy, no test of significance could be applied.

The changes in 'arginine synthetase' activity with the different regimens are shown in Fig. 2. Supplementation with approximately $73 \mathrm{~g}$ protein/d for $\mathrm{I}$ week, after a period of 6 weeks on the basal diet, resulted in a significant increase in 'arginine synthetase' activity $\left(P<0^{\circ} \circ \mathrm{I}\right)$ compared with the control group given the basal diet 


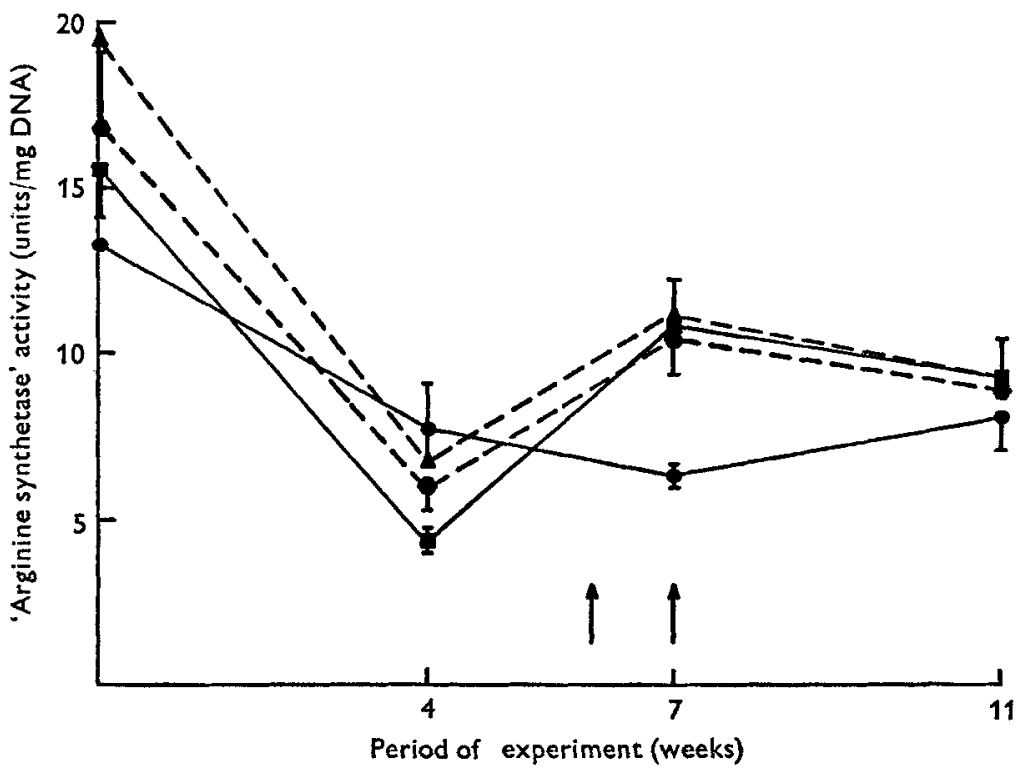

Fig. 2. Expt I. The changes in liver 'arginine synthetase' activity (combined argininosuccinate synthetase $(E C 6.3 .4 .5)$ and argininosuccinate lyase $(E C 4.3 .2 .1)$ activities) in groups of sheep during the experimental period when they were given different feeding regimens (for details, see Table $\mathrm{I}$ ). $(\uparrow)$, The $7 \mathrm{~d}$ supplementation period when the sheep received the following diets $(\mathrm{g} / \mathrm{d})$ : group $\mathrm{I}, 500$ Rhodes-grass (Chloris gayana) chaff (basal) (-); group 2, basal + 500 lucerne (Medicago sativa) chaff (-); group 3, basal +170 safflower meal ( $\mathbf{A}-\mathbf{A})$; group 4, basal + 500 lucerne chaff + r70 safflower meal ( $-\boldsymbol{D}$ ). After the supplementation period the sheep were returned to pasture. Each point represents the mean value for the group, with the standard errors represented by vertical bars. One unit of enzyme activity was defined as $\mathrm{I} \mu \mathrm{mol}$ ammonia formed/h at $38^{\circ}$.

\section{Table 2. Expts $\mathrm{I}$ and 2. The effects of different dietary regimens on the live weights of groups of sheep}

(Mean values for four animals/group for Expt I and for six animals/group for Expt 2, except for those indicated in parentheses for week II)
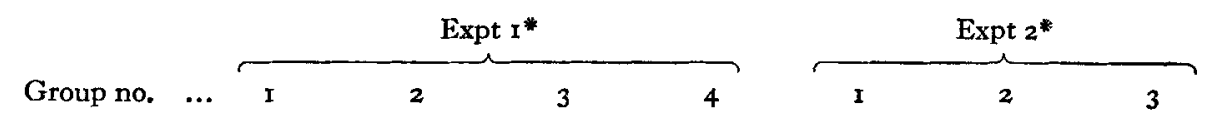

Experimental period (weeks)

\begin{tabular}{|c|c|c|c|c|c|c|c|}
\hline (weeks) & & & & & & & \\
\hline 0 & $38 \cdot 1$ & $3^{6 \cdot 2}$ & $37 \cdot 6$ & $3^{6 \cdot 9}$ & 33.0 & $32 \cdot 9$ & $32 \cdot 5$ \\
\hline 4 & $3^{6 \cdot 0}$ & $34^{\circ} 5$ & $35 \cdot 2$ & $35^{-2}$ & $26 \cdot 8$ & $26 \cdot 7$ & $26 \cdot 8$ \\
\hline 6 & $35^{\cdot 6}$ & $34 \cdot 2$ & 347 & $35^{\cdot I}$ & $25 \cdot 3$ & $25 \cdot 3$ & $26 \cdot 6$ \\
\hline 7 & $34^{\circ} 9$ & $36 \cdot 2$ & $37 \cdot 2$ & $37 \cdot 6$ & $24^{-6}$ & $24 \cdot 5$ & $26 \cdot 5$ \\
\hline & $35.4(\mathrm{I}) \dagger$ & $36 \cdot 5$ & $37 \cdot 8$ & $37 \cdot 2$ & $29 \cdot 0(3) \dagger$ & $32 \cdot 2$ & $32 \cdot 1(3) \dagger$ \\
\hline
\end{tabular}

* For details of animals and dietary regimens, see Table $\mathrm{I}$ and p. 48.

+ Animals remaining in these groups after some had died as a result of urea toxicity. 


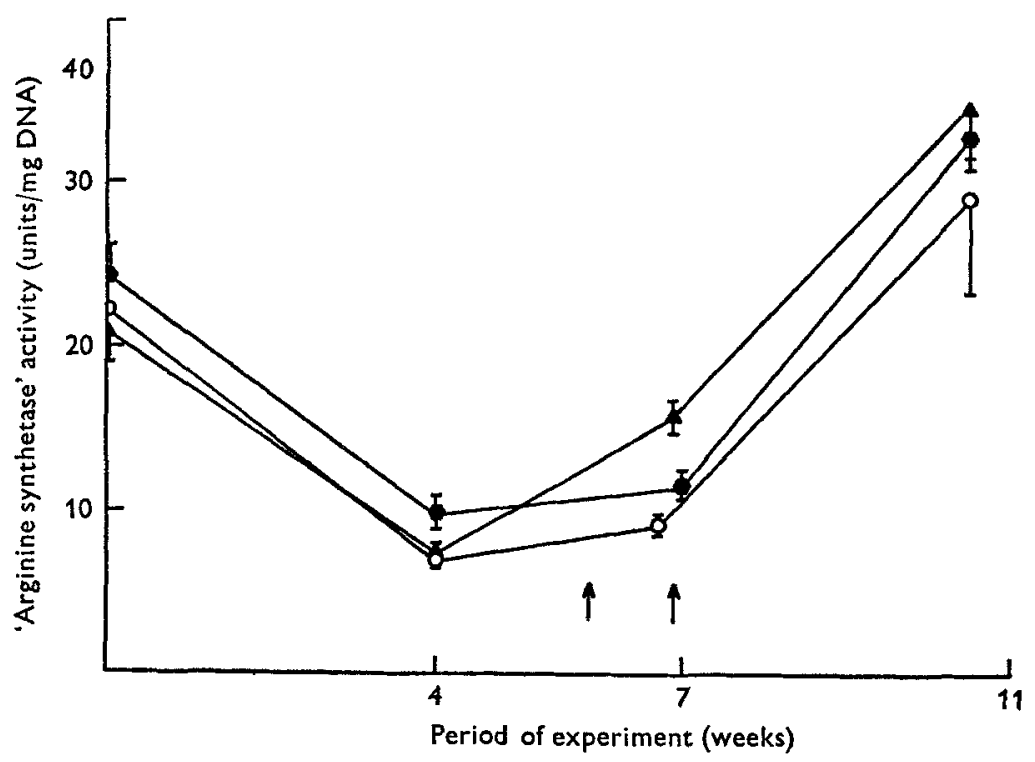

Fig. 3. Expt 2. The changes in liver 'arginine synthetase' activity (combined argininosuccinate synthetase $(E C 6.3 .4 .5)$ and argininosuccinate lyase $(E C 4.3 .2 .1)$ activities) in groups of sheep during the experimental period when they were given different dietary regimens (for details, see Table $\mathrm{I}) .(\uparrow)$, The $7 \mathrm{~d}$ supplementation period when the sheep received the following diets (g/d): group I, 400 Rhodes-grass (Chloris gayana) chaff (basal) (O-O); group 2, basal + I70 safflower meal (A-A); group 3, basal + I $_{50}$ molasses (-). After the supplementation period the sheep were given lucerne (Medicago sativa) chaff ad lib. At 7 weeks the groups were sampled I d apart to allow urea tolerance tests to be done. Each point represents the mean value for the group, with the standard errors represented by vertical bars. One unit of enzyme activity was defined as I $\mu \mathrm{mol}$ ammonia formed $/ \mathrm{h}$ at $38^{\circ}$.

alone, though the activity was still below the initial levels determined after the preliminary period, when the animals were taken off pasture. There was no difference between lucerne chaff and safflower meal supplementation either in urea tolerance or in enzyme activity. Giving twice the protein intake also did not result in further changes in enzyme activity.

Although they were consuming only $500 \mathrm{~g}$ Rhodes-grass chaff/d, the sheep had only a small decrease in live weight, particularly after 4 weeks ('Table 2).

\section{Expt 2}

The peak blood $\mathrm{NH}_{3}-\mathrm{N}$ levels for each sheep after drenching with urea are shown in Fig. I. All sheep with a blood $\mathrm{NH}_{3}-\mathrm{N}$ level greater than $0^{\cdot} 143 \mu \mathrm{mol} / \mathrm{ml}$ died. The urea dose $\left(0.45 \mathrm{~g} / \mathrm{kg}\right.$ live weight) appeared to be the median lethal dose $\left(\mathrm{LD}_{50}\right)$ for this basal diet. Group 2 (supplemented with safflower meal) showed no signs of toxicity. Feeding a molasses supplement for 7 weeks (group 3 ) did not result in any significant decrease in toxicity since three of the six sheep in the group died. The onset of symptoms of toxicity however appeared to be delayed by approximately $\mathrm{I} h$. The blood $\mathrm{NH}_{3}-\mathrm{N}$ levels were similar to those of the control group (group I) although the time taken to reach the maximum blood $\mathrm{NH}_{3}-\mathrm{N}$ level was delayed. 
Although protein and energy deprivation was more severe in Expt 2, 'arginine synthetase' activity was reduced to a level comparable to that in Expt I (Fig. 3). The effect of the safflower supplement was similar to that in Expt $I$, i.e. the 'arginine synthetase' activity was partially restored $(P<0.01)$. The levels of 'arginine synthetase' activity found in the molasses-supplemented sheep at 4 and 7 weeks tended to be higher than those in the sheep given the basal diet. At 7 weeks the level of 'arginine synthetase' activity/mg DNA in molasses-supplemented sheep was significantly higher $(P<0.05)$, although 'arginine synthetase' activity/g wet weight was not different from control levels.

In contrast with Expt I the sheep given $400 \mathrm{~g}$ Rhodes-grass chaff/d had a marked loss in live weight (Table 2). The possible negative correlation between peak blood $\mathrm{NH}_{3}-\mathrm{N}$ and 'arginine synthetase' activity was tested but was not significant.

\section{DISCUSSION}

The results indicated that short-term feeding of a protein supplement to sheep in a state of undernutrition increased the activity of at least some of the enzymes of the urea cycle in liver and decreased the toxicity of a given dose of urea. The response was similar with 73 or $146 \mathrm{~g}$ protein/d and supplementation with $73 \mathrm{~g}$ protein/d, for sheep of about $32 \mathrm{~kg}$ body-weight, is maximal. A lower amount may be adequate. Perhaps greater response could be obtained by giving the supplement for a period longer than I week. The levels of blood $\mathrm{NH}_{3}-\mathrm{N}$ in the protein-supplemented group suggest that a larger dose of urea would cause toxicity and therefore, if possible, it would be desirable to further increase the 'arginine synthetase' activity.

The failure of the 'arginine synthetase' levels to return to initial levels after return to pasture, in Expt I, was attributed to deterioration of the pasture. This led to the different design of Expt 2 in which, to avoid this situation, lucerne chaff was fed ad lib. as the preliminary and final diets.

The similar response with either lucerne chaff or safflower meal suggests that the protein source is not important. Tagari, Krol \& Bondi (1965), however, reported that proteins such as those of lucerne and soya bean are degraded at different rates in the rumen. Soya-bean meal was found to produce a lower level of amino acid resynthesis, therefore $\mathrm{NH}_{3}$ enters the bloodstream in greater amount. Schimke (1962, 1963) suggests that increased protein catabolism, with consequently increased requirement for urea synthesis, is the controlling factor for urea-cycle enzymes. Hence, any protein supplement which results in increased absorption of ammonia is likely to be more efficient at increasing the concentration of urea-cycle enzymes. In this respect it is possible that protein supplements such as soya-bean meal may be more effective.

In previous studies (Payne \& Morris, 1969) the change in 'arginine synthetase' activity was expressed on a wet weight basis or per mg protein. In the present work the activity was expressed per mg DNA. In general the same level of statistical significance was obtained whatever the method of expression, except in the instance of the molasses-supplemented group. Although activity per $\mathrm{g}$ wet weight usually showed lower variance than would be expected, the activity per mg DNA showed greater change and only these values have been given. 
Although there was no statistically significant correlation between 'arginine synthetase' activity and peak blood $\mathrm{NH}_{3}-\mathrm{N}$ concentration, this is probably not surprising because the number of animals in a toxic condition was relatively small. In addition, while it is considered that these enzymes are a limiting factor in the removal of blood $\mathrm{NH}_{3}$, there are also other factors which limit absorption of $\mathrm{NH}_{3}$ from the rumen into the bloodstream. These factors such as rumen buffer capacity, rumen motility, differences in rumen volume and, therefore, $\mathrm{NH}_{3}$ concentration, and rumen blood flow, possibly are the cause of the absence of high blood $\mathrm{NH}_{3}$ levels in some of the control sheep.

In the instance of the molasses-supplemented group it was thought that giving energy in the form of molasses might spare some gluconeogenesis and result in higher enzyme levels and greater tolerance to urea. This is apparently unimportant, but the longer period required for toxicity to develop may be related to the slight increase in enzyme activity found or to an increase in buffering capacity of the rumen as a result of feeding with a molasses supplement. No food was offered to any of the sheep after 08.00 hours on the day before the liver biopsy and urea drenching. If the sheep had been allowed to feed just before the liver biopsy and urea drenching, almost certainly the buffering effect of the molasses would have increased their tolerance to urea (Austin, I967).

By comparing the results of the two experiments it was concluded that the loss in live weight was no indicator of urea tolerance, because both control groups had similar tolerances. Thus sheep lose their urea tolerance before any important loss in live weight.

The authors are indebted to members of the Husbandry Research Section for feeding the sheep and to Mr J. O. Twist and Mr A. May of the Biochemistry Section for technical assistance.

\section{REFERENCES}

Austin, J. (1967). In Urea as a Protein Supplement, p. I80 [M. H. Briggs, editor]. Oxford: Pergamon Press.

Brown, G. W. \& Cohen, P. P. (I959). F. biol. Chem. 234, 1769.

Dick, A. T. (1952). Aust. vet. F. 28, 234.

Giles, K. W. \& Myers, A. (1965). Nature, Lond. 206, 93.

Lewis, D. (1957). F. agric. Sci., Camb. 48, 438.

Miller, G. L. (1959). Analyt. Chem. 31, 964.

Morris, J. G. \& Payne, E. (1970). J. agric. Sci., Camb. 74, 259.

Munro, H. N. \& Fleck, A. (1966). Meth. biochem. Analysis 14, I 13.

Payne, E. \& Morris, J. G. (1969). Biochem. F. 113, 659.

Schimke, R. T. ( (1962). F. biol. Chem. 237, 459.

Schimke, R. T. (1963). F. biol. Chem. 238, ro12.

Seligson, D. \& Seligson, H. ( 95 I). F. Lab. clin. Med. 38, 324.

Tagari, H., Krol, O. \& Bondi, A. (1965). Nature, Lond. 206, 37. 